\title{
SEL PUNCA
}

\section{Thontowi Djauhari NS,*}

\begin{abstract}
Abstrak
Penggunaan dan pengembangan sel punca dalam bidang penelitian dan aplikasinya diklinik dalam rangka mengobati penyakit tidak. terlepas dari masalab etik yang mungkin membayanginya, kbususnya penggunaan dan pemanfaatan sel punca yang berasal dari embrio (embryonic stem cells). Dasar pengetabuan sel punca merupakan bal yang penting untuk diketabui karena dari sana bisa dikembangkan sel punca tersebut akan berubab menjadi sel permanen. Penggunaan sel punca dalam bidang penelitian dan pengobatan penyakit tidak terlepas dari etika yang dianut untuk menghormati sel punca tersebut, karena masib banyak kontroversi terbadap pengadaan sel punca.
\end{abstract}

Kata kunci : sel punca

\section{Pendahuluan}

Kata sel Punca mulai populer digunakan di dunia kedokteran sekitar pertengahan 2008, kosa kata tersebut diambilkan dari kata stem cell yang mulai populer digunakan tahun 1950 scjak ditemukannya tahun 1908, istilah "stem cell" pertama kali diusulkan oleh histolog Russia, Alex ander Maksimov, pada kongres hematologi di Berlin. Ia mempostulatkan adanya sel induk yang membentuk sel-sel darah. Tahun 1978, terbukti teori ini betul dengan ditemukannya sel-sel punca di darah sumsum tulang belakang manusia yang mampu membentuk seluruh jenis sel darah dalam tubuh manusia. Jenis stem cell dalam sum-sum tulang disebut sebagai bematopoietic stem cell.

Sesuai dengan kata yang menyusunnya (stem =batang; cell $=\mathrm{sel})$, adalah awal mula dari pembentukan berbagai sel penyusun keseluruhan tubuh manusia. Oleh katena itu dalam bahasa Indonesia istilah stem cell diterjemahkan menjadi sel punca yang berarti (punca $=$ awal mula),kata ini bersama sel induk diusulkan oleh Komisi Bioetika Nasional dan telah disetujui oleh Pusat Bahasa untuk mengindonesiakan istilah stem cell.

Makna yang terkandung dalam kata sel punca semakin diteguhkan dengan penemuan keberadaan sel punca pada awal kehidupan ketika saat masih embrio. Hal ini tentunya semakin menegaskan bahwa sel punca adalah sel yang menjadi awal mula terbentuknya sekitar 200 jenis sel yang menyusun tubuh (Danny,2010)

Pada dekade terakhit penelitian dalam bidang sel punca mengalami kemajuan pesat, hal ini desebabkan karena potensi sel punca yang sangat menjajikan untuk mengetahui proses perkembangan jatingan tubuh manusia, pengobatan serta patogenesis penyakit. Tentu saja potensi dalam bidang penelitian dan pengobatan tidak terlepas dari potensi nilai bisnis yanga akan diraih.

\footnotetext{
* Staff Pengajar Pada Fakultas Kedokteran

Universitas Mubammadiyab Malang
}

Penggunaan dan dan pengembangan sel punca dalam bidang penelitian dan aplikasinyadi klinik dalam rangka mengobati penyakit idak terlepas dari masalh etik yang mungkin membayangi, khususnyapenggunan dan pemanfaatan sel punca yang berasal dari embrio (Ahmad, 2008)

Dalam tulisan ini akan dibahas mengenai sejarah perkembangan sel punca, definisi sel punca, jenis dan sifatnya serta etika dalam pemakaian sel punca.

\section{Sekilas Perjalanan Sel Punca}

Pada tikus, penelitian sel punca bermula pada tahun 1981. Penelitian untuk menurunkan sel punca dari embrio manusia berawal tahun 1998. Pada akhitnya, penelitian sel punca dari embrio manusia memicu banyak pro kontra terkait masalah etika, bahwa penggunaan sel punca yang berasal dari embrio harus mengorbankan embrio tersebut. Sekilas perjalanan sel punca adalah sebagai berikut. Stem cell (2010)

1908 - Kata stem cell mulai di ajukan oleh histologist Alexander Maksimov (1874-1928) pada kongres hematologi di Berlin. Bahan dasar yang diajukanberasal dari haematopoietic stem cells.

Tahun 1981 : sel punca yang berasal embrio pertama kali diisolasi oleh dua kelompok : Gail Martin di University of California, San Fransisco, dan Martin Evans, University of Cambridge.

November 1995 : Peneliti di University of Winconsin mengisolasi sel punca embrio primata pertama, monyet rbesus macaque. Hasil penelitian menunjukkan ada kemungkinan untuk menurunkan sel punca embrio dati primata, termasuk manusia.

Januari 1998 : Ilmuwan dan enterpreneur Richard Seed mengumumkan rencana untuk membuka klinik kloning 
manusia. Klinik tersebut akan menawarkan pasangan yang tidak subur untuk mengkloning diri mereka jika tidak ada terapi medik yang dapat dilakukan untuk mendapatkan anak. Rencana Seed tersebut memicu debat mengenai kloning manusia.

5 November 1998 : Peneliti di University of Wisconsin dan Jobn Hopkins University melaporkan sel punca yang diisolasi dari embrio manusia. Sel tersebut memiliki potensi untuk tumbuh menjadi berbagi tipe sel dalam tubuh dan dapat digunakan untuk menggantikan sel-sel yang rusak. Namun prosesnya kontroversial : Tim pertama menurunkan stem sel dari jaringan fetus yang teraborsi, tim yang lain dari embrio yang dihasilkan di laboratorium yang berasal dari pasangan yang menjalani in vitro fertilization.

23 Agustus 2000 : The National Institutes of Health mengeluarkan panduan yang memungkinkan badan federal Amerika membiayai penelitian sel punca embrio. Mantan Presiden Bill Clinton mendukung panduan ini.

Febuari 2001 : Presiden George W. Bush meminta untuk mengkaji ulang panduan The National Institutes of Health dan menunda dana federal yang digunakan untuk penelitian sel punca.

18 Juli 2001 : Senator Bill Frist dan Senator Orrin Hatch, yang merupakan kelompok anti aborsi, menyetujui pembatasan dana federal untuk penelitian sel punca.

9 Agustus 2001 : Presiden Bush mengeluarkan keputusan bahwa dana federal hanya dapat digunakan untuk penelitian sel punca embrio embrio yang telah tersedia, dari sumber yang tertinggal di klinik fertilisasi.

25 November 2001 : Ilmuwan di Advanced Cell Technology di Massachusetts mengklaim telah mengkloning embrio manusia. Namun, pembuktiannya kontroversial dan tidak konklusif

12 Februari 2004 : Ilmuwan Korea Selatan yang diketuai oleh Hwang Woo Suk mengumumkan kloning embrio pertama di dunia. Tidak seperti klaim kloning sebelumnya, para ilmuwan ini melaporkan hasil kerja mereka di jurnal yang prestisius, peer-review, Science. Embrio dikloning bukan untuk tujuan reproduksi tapi sebagai sumber sel punca. Berita tersebut membuka kembali pertentangan tentang transfer inti sel somatik. Ilmuwan mengatakan kloning menawarkan cara yang unik untuk memproduksi sel yang suatu saat bisa digunakan untuk terapi penyakit. Namun pihak yang mengkritik beragumen bahwa kloning dalam bentuk apapun tidak sesuai dengan nilai moral dan harus dilarang.

19 Mei 2005 : Ilmuwan yang sama dari Korea Selatan melaporkan telah mengkloning embrio manusia pada tahun 2004, mengumumkan bahwa mereka telah membuat proses yang menggunakan sel telur manusia yang jauh lebih sedikit untuk memproduksi stem sel embrio.
19 September 2005 : Ilmuwan di California melaporkan bahwa menyuntikkan sel punca saraf dapat memperbaiki spinal cord tikus.

11 November 2005 : Peneliti University of Pittsburgh Gerald Schatten memperingatkan editor Science bahwa terdapat kemungkinan kesalahan dalam paper ilmuwan Korea Selatan bulan Februari 2004. Dalam paper tersebut, ilmuwan Korea mengklaim mereka telah membuat sel puncal line dari kloning embrio manusia. Schatten mengatakan bahwa beberapa donor sel telur dalam penelitian itu telah dibayar.

15 Desember 2005 : Ilmuwan Korea Selatan, mengakui adanya kesalahan yang serius dalam papernya di tahun 2005 dan meminta Science untuk menarik kembali jurnal tersebut.

29 Desember 2005 : Investigasi Seoul National University menyimpulkan data penelitian tim Hwang yang dipublikasikan Science adalah palsu.

12 Januari 2006 : Jurnal Science secara formal menarik dua artikel Hwang.

7 Juni 2006 : Harvard university mengumumkan program multimillion-dollar untuk membuat kloning embrio manusia sebagai sumber menjanjikan sel punca.

18 Juli 2006 : Presiden Bush melarang aliran dana federal untuk membiayai penelitian sel punca embrio.

Oktober 2007 - Mario Capecchi, Martin Evans, dan Oliver Smithies Mendapat hadiah nobel 2007 bidang fisiologi kedokteran untuk menjelaskan sel punca embrionik dari tikus dan pemanfaatannya untuk penelitian gen.

Januari 2008 - Robert Lanza and colleagues at Advanced Cell Technology and UCSF membuat pertama kali sel punca embrionik manusia tanpa merusak embrio

30 Oktober 2008 - Embrionik menyerupai sel punca berasal dari rambut manusia.

28 Mei $2009 \mathrm{Kim}$ et al. Mengumumkan cara memanipulasi dari sel kulit yang dipakai oleh pasien "induced pluripotent stem cells" (iPS),

11 Oktober 2010 Percobaan pertama kali pada embrio sel punca yang berasal dari manusia.

\section{Karakteristik Sel Punca}

Sel punca merupakan sel yang belum berdiferensiasi dan mempunyai potensi yang sangat tinggi untuk berkembang menjadi banyak jenis sel yang berbeda di dalam tubuh. Sel punca juga berfungsi sebagai sistem perbaikan untuk mengganti sel-sel tubuh yang telah rusak demi kelangsungan hidup organisme Saat sel punca 
terbelah, sel yang baru mempunyai potensi untuk tetap menjadi sel punca atau menjadi sel dari jenis lain dengan fungsi yang lebih khusus, misalnya sel otot, sel darah merah atau sel otak.

Sel punca memiliki dua sifat penting yang sangat berbeda dengan sel yang lain:

- Sel punca belum merupakan sel dengan spesialisasi fungsi tetapi dapat memperbaharui diri dengan pembelahan sel bahkan setelah tidak aktif dalam waktu yang panjang

- Dalam situasi tertentu, sel punca dapat diinduksi untuk menjadi sel dengan fungsi tertentu seperti sel jaringan maupun sel organ yang mempunyai tugas tersendirj. Pada sumsum tulang dan darah tali pusar (bahasa Inggris: umbilical cord blood), sel punca secara teratur membelah dan memperbaiki jaringan yang rusak, meski demikian pada organ lain seperti pankreas atau hati, pembelahan hanya terjadi dalam kondisi tertentu.
Peneliti medis meyakini bahwa penelitian sel punca berpotensi untuk mengubah keadaan penyakit manusia dengan cara digunakan memperbaiki jaringan atau organ tubuh tertentu. Namun demikian, hal ini tampaknya belum dapat benar-benar diwujudkan dewasa ini.

Sel-sel induk dapat digolongkan berdasarkan potensi yang dimiliki oleh sel tersebut maupun berdasarkan asalnya.

\section{Berdasarkan potensi}

Sel induk adalah sel terspesialisasi yang memiliki dua sifat menentukan: kemampuan untuk membedakan menjadi sel lain dan kemampuan untuk diri-regenerasi .

Kemampuan untuk membedakan adalah potensi untuk berkembang menjadi jenis sel lain. Totipotensi sel induk (misainya telur dibuahi) dapat berkembang menjadi semua tipe sel termasuk membran embrio. Pluripotensi sel induk dapat berkembang menjadi sel-sel semua berasal dari endoderm, ektoderm dan mesoderm, sel tersebut dapat oligopotent, bipotent atau unipotent tergantung pada kemampuan mereka untuk betkembang menjadi jenis lainnya sel.

\begin{tabular}{|c|c|c|c|}
\hline Diferensiasi Potensi & Jumlah jenis sel & Contoh sel & $\begin{array}{l}\text { Jenis sel yang dihasilkan dari } \\
\text { diferensiasi }\end{array}$ \\
\hline Totipotential (toti=total) & Semua & $\begin{array}{l}\text { blastomere Zigot (telur dibuahi), } \\
\text { blastomere }\end{array}$ & Semua jenis sel \\
\hline $\begin{array}{l}\text { Pleuripotential } \\
\text { (pluri=jamak) }\end{array}$ & $\begin{array}{l}\text { Semua membran } \\
\text { kecuali sel dari } \\
\text { membran embrio }\end{array}$ & $\begin{array}{l}\text { Sel embrional (ektoderm, } \\
\text { endoderm, mesoderm) }\end{array}$ & Semua jenis sel \\
\hline Multipotential & Banyak & Hematopoietic sel & $\begin{array}{l}\text { otot rangka, otot jantung, sel hati, } \\
\text { semua sel darah }\end{array}$ \\
\hline Oligopotential & Beberapa & Jaringan Myeloid atau limfoid & $\begin{array}{c}5 \text { jenis sel darah (Monosit, makrofag, } \\
\text { eosinofil, neutrofil, eritrosit) }\end{array}$ \\
\hline Quadripotential & 4 & Mesenchymal progenitor cell & $\begin{array}{l}\text { Sel-sel tulang rawan, sel-sel lemak, sel } \\
\text { stroma, pembentuk sel-sel tulang }\end{array}$ \\
\hline Tripotential & 3 & $\begin{array}{l}\text { Glial-restricted precursor Glial- } \\
\text { dibatasi prekursor }\end{array}$ & 2 jenis astrosit, oligodendrocytes \\
\hline Bipotential & 2 & $\begin{array}{l}\text { Bipotential prekursor dari hati } \\
\text { janin murin }\end{array}$ & Sel-sel B, makrofag \\
\hline $\begin{array}{l}\text { Unipotential } \\
\text { (uni=tunggal) }\end{array}$ & 1 & Mast sel prekursor & Sel Mast \\
\hline Nullipotential & Tak satupun & $\begin{array}{c}\text { akhir dari sel misalnya sel darah } \\
\text { merah }\end{array}$ & pembelahan sel \\
\hline
\end{tabular}

Tabel 1: Perbedaan potensi dari sel punca totipoten ke sel nullipotent. Dikompilasi dari informasi dalam sumber-sumber yang ditampilkan. Cumano (1992), Rao M.S (1998), Dennis (1999), Sell, S. (2004), Ulloa (2005).Tuch BE (2006), Kintisch, (2006), Hans R. Schöler (2007), Ahmad (2008), Mitalipov S, Wolf D' (2009), Danny (2010) 


\section{Berdasarkan asainya Sel punca embrio (embryonic stem cells)}

Sel induk ini diambil dari embrio pada fase blastosit (5-7 hari setclah pembuahan). Massa sel bagian dalam mengelompok dan mengandung sel-sel induk embrionik. Sel-sel diisolasi dari massa sel bagian dalam dan dikultur secara in vitro. Sel induk embrional dapat diarahkan menjadi semua jenis sel yang dijumpai pada organisme dewasa, seperti sel-sel darah, sel-sel otot, selsel hati, sel-sel ginjal, dan sel-sel lainnya.

\section{Sel germinal/benih embrionik (embryonic germ cells)}

Sel germinal/benih (seperti sprema/ovum) embrionik induk/primordial (primordial germ cells) dan prekursor sel germinal diploid ada sesaat pada cmbrio sebelum mereka terasosiasi dengan sel somatik gond dan kemudian menjadi sel germinal Sel germinal embrionik manusia/human embryonic germ cells (hEGCs) termasuk sel punca yanig berasal dari sel germinal primordial dari janin berumut 5-9 minggu. Sel punca jenis ini memilki sifat pluripotensi.

\section{Sel punca fetal}

Sel punca fetal adalah sel primitif yang dapat ditemukan pada organ-organ fetus (janin) seperti sel punca hematopoietik fetal dan progenitor kelenjar pankreas. Sel punca neural fetal yang ditemukan pada otak janin menunjukkan kemampuan untuk berdiferensiasi menjadi sel neuron dan sel glial (scl-sel pendukung pada sistem saraf pusat). Darah, plasenta, dan tali pusat janin kaya akan sel punca hematopoietik fetal.

\section{Sel punca dewasa (adult stem cells)}

Sel punca dewasa mempunyai dua karakteristik. Karakteristik pertama adalah sel-sel tersebut dapat berprolifcrasi untuk periode yang panjang untuk memperbarui diri. Karakteristik kedua, sel-sel tersebut dapat berdiferensiasi untuk menghasilkan sel-sel khusus yang mempunyai karakteristik morfologi dan fungsi yang spesial.

\section{Sel punca hematopoietik}

Salah satu macam sel induk dewasa adalah sel induk hematopoietik (bematopoietic stem cells), yaitu sel induk pembentuk darah :yang mampu membentuk sel darah merah, sel darah putih, dan keping darah yang sehat Sumber sel induk hematopoietik adalah sumsum :tulang, darah tepi, dan darah tali pusar. Pembentukan sel induk hematopietik terjadi pada tahap awal embriogenesis, yaitu dari mesoderm dan disimpan pada situs-situs spesifik di dalam embrio.

\section{Sel punca mesenkimal}

Sel induk mesenkimal/ mesenchymal stem cells (MSC)dapat ditemukan pada stroma sumsum tulang belakang, periosteum, lemak, dan kulit. MSC termasuk sel induk multipontensi yang dapat berdiferensiasi menjadi sel-sel tulang, otot, ligamen, tendon, dan lemak. Namun ada beberapa bukti yang menyatakan bahwa sebagian MSC bersifat pluripotensi sehingga tidak hanya dapat berubah menjadi jaringan mesodermal tetapi juga endodermal.

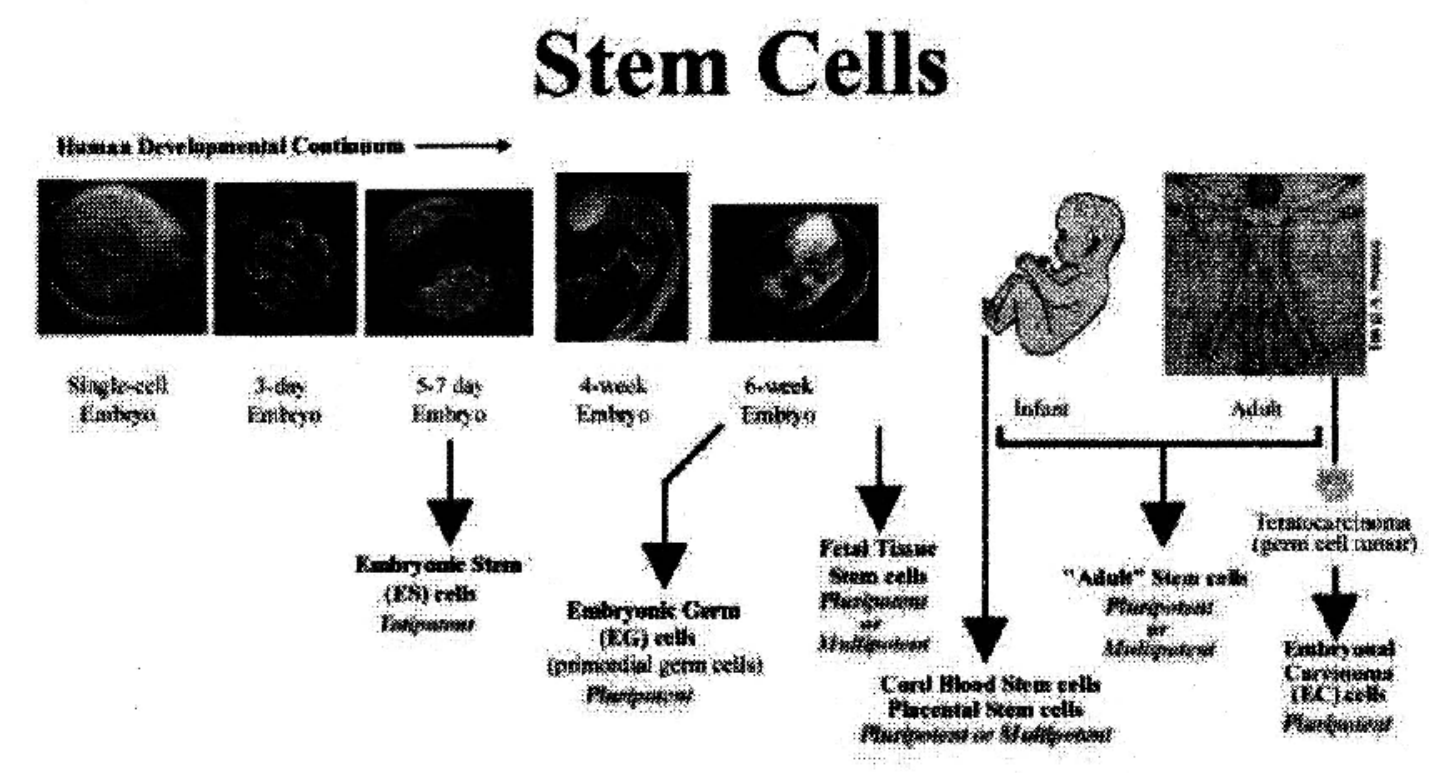

http://wwwprayersforthepeople.com/id70.html, maret 2009 


\section{Bioetika Pada Penelitian Stem Cells}

Manfaat yang diperoleh dari penggunaan sel punca embrionik (embryonic stem cell) dalam bidang kedokteran amat besar, namun sumber sel punca embrionik ini merupakan masalah etika yang perlu mendapat perhatian.

Berkembangnya penelitian sel punca dan penggunaan sel punca dalam upaya untuk mengobati penyakit pada manusia akan mengakibatkan timbulnya masalah dalam hal etik. Hal utama terkait dengan masalah etik adalah sumber sel punca tersebut. Berbagai masalah etika yang perlu dipikirkan adalah

1. Apakah penelitian embrio manusia secara moral dapat dipertanggung jawabkan?

2. Apakah penelitian embrio yang menyebabkan kematian embrio merupakan pelanggaran terhadap hak azasi manusia (HAM) dan berkurangnya penghormatan terhadap mahluk hidup?

3. Apakah penyalah gunaan dapat diketahui dan dikendalikan?

4. Apakah penggunaan embrio sisa proses bayi tabung pada penelitian diperbolehkan?

5. Apakah penelitian khusus membuat embrio untk digunakan diperbolehkan?

Isu bioetika utama dalam penelitian dan penggunaan stem cell adalah penggunaan sel punca embrio terutama tentang sumber sel tersebut yaitu embrio. Sumber embrio adalah hasil abortus, zigot sisa IVF dan hasil pengklonan. Pengklonan embrio manusia untuk memperoleh stem cell merupakan isu yang sangat menimbulkan kontroversi. Hal ini terkait dengan isu "awal kehidupan" dan penghormatan terhadap kehidupan. Pengklonan embrio manusia untuk memperoleh sel punca menimbulkan kontroversi karena berhubungan dengan pengklonan manusia yang ditentang oleh semua agama. (Ahmad, 2008)

Undang - undang Republik Indonesia no 36 tahun 2009 tentang Kesehatan pasal 70 mengatakan :

(1)Penggunaan sel punca hanya dapat dilakukan untuk tujuan penyembuhan penyakit dan pemulihan kesehatan, serta dilarang digunakan untuk tujuan reproduksi.

(2) Sel punca sebagaimana dimaksud pada ayat (1) tidak boleh berasal dari sel punca embrionik. (3) Ketentuan lebih lanjut mengenai penggunaan sel punca sebagaimana dimaksud pada ayat (1) dan ayat (2) diatur dengan Peraturan Menteri.

Pasal 70 Ayat (1)Yang dimaksud dengan "sel punca" dalam ketentuan ini adalah sel dalam tubub manusia dengan kemampuan istimewa yakni mampu memperbabarui atau meregenerasi dirinya dan mampu berdiferensiasi menjadi sel lain yang spesifik.
Dalam proses pemanenan sel punca embrio dapat terjadi kerusakan pada embrio dan menyebabkan embrio tersebut mati. Adanya anggapan bahwa embrio berstatus sama dengan manusia menyebabkan hal tersebut tidak dapat diterima. Perdebatan yang cukup ramai adalah mengenai status moral embrio, apakah embrio harus diperlakukan sebagai manusia atau sebagai sesuatu yang berpotensi untuk menjadi manusia atau sebagai jaringan hidup tubuh lainnya. Lebih jauh lagi apakah embrio yang berkembang dianggap sebagai mahluk hidup.

Penggunaan sel punca yang berasal dari surplus zigot pembuatan bayi tabung sendiri. juga menimbulkan kontroversi. Pendapat yang moderat mengatakan daripada surplus zigot itu dibuang, sebaiknya dipakai saja untuk penelitian. Sebaliknya ada juga yang berpendapat bahwa sisa itu harus dipelihara hingga zigot itu mati.

\section{Daftar Pustaka}

Ahmad(2008), Aspek Dasar Sel Punca Embrionik (Embryonic Stem Cells) dan Potensi Pengembangannya, Dipresentasikan pada diskusi panel Realitas baru dan prospek perkembangan seputar terapi sel punca, Dipresentasikan pada diskusi panel Realitas baru dan prospek perkembangan seputar terapi sel punca (stem cell), R. Rapat PB IDI, Jakarta, Sabtu 24 Mei 2008

Cumano A., Paige C.J., Iscove N.N., Brady G. (1992) Bipotential precursors of $\mathrm{B}$ cells and macrophages in murine fetal liver. Nature 356, 612-615.

Danny et all (2010), STEM CELL, Dasar Teori \& Aplikasinya, Penerbit Erlangga

Dennis, J.E., Merriam, A., Awadallah, A., Yoo, J. U., Johnstone, B., Caplan, A. I. (1999) A quadripotential mesenchymal progenitor cell isolated from the marrow of an adult mouse J. Bone Miner. Res. 14, 700-709

Hans R. Schöler (2007). "The Potential of Stem Cells: An Inventory". In Nikolaus Knoepffler, Dagmar Schipanski, and Stefan Lorenz Sorgner. Humanbiotechnology as Social Cballenge. Ashgate Publishing, Ltd. p. 28. ISBN 0754657558.

http://wwwprayersforthepeople.com/id 70.html, maret 2009

Kintisch, Eli (July 18, 2006) “Groups Target Stem Cell Patents." ScienceNOW Daiby Newys. Retrieved August $15,2006$. 
Mitalipov S, Wolf D (2009). "Totipotency, pluripotency and nuclear reprogramming". Adv. Biochem. Eng. Biotechnol. 114: 185-99.

Rao M.S., Noble M., Mayer-Proschel M. (1998) A tripotential glial precursor cell is present in the developing spinal cord. Proc Natl Acad Sci USA. 95, 3996-4001

Sell, S. (2004) Stem cells. Stem Cell Handbook, Humana Press, edited by Sell, S.

Stem Cell Information, http://stemcells.nih.gov/info/ scireport/chapter4.asp (National Institute of Health)

Stem cell (2010), Wikipedia, the free encyclopedia. .mikipedia.org/wiki/Stem_cell

Tuch BE (2006). "Stem cells - a clinical update". Australian Family Pbysician 35 (9): 719-21.

Ulloa-Montoya F, Verfaillie CM, Hu WS (Jul 2005). "Culture systems for pluripotent stem cells". J Biosci Bioeng. 100 (1): 12-27.

Undang-undang Republik Indonesia Nomor 36 Tahun 2009 Tentang 